\title{
Purification and characterization of protease from Bacillus thuringiensis isolated from soil
}

\author{
Önder İdil ${ }^{1 * \text { ID }}$, Üzeyir Söylemez ${ }^{2}$ ID, Emine Çelikoğlu ${ }^{3}$ ID, Umut Çelikoğlu $^{4}$ \\ ${ }^{1}$ Faculty of Education, Amasya University, Amasya/Turkey \\ ${ }^{2}$ Ankara Polatlı Duatepe Public Hospital, Ankara/ Turkey \\ ${ }^{3}$ Department of Biology, Faculty of Arts and Sciences, Amasya University, Amasya/Turkey \\ ${ }^{4}$ Amasya University, Central Research Laboratory, Amasya/Turkey
}

\begin{abstract}
Proteases are one of the most important groups of industrial enzymes. These enzymes are used in detergent, protein, meat, leather, dairy, pharmaceutical and food industry. In this study, protease enzymes produced from Bacillus thuringiensis which was isolated from soil was purified. The optimum conditions of this purified enzyme were investigated. The effect of the different production environment, different $\mathrm{pH}$, different temperature degrees and different metal ions of the enzyme produced from Bacillus thuringiensis were observed. It was seen that the highest protease activity was at $55^{\circ} \mathrm{C}$ and at $\mathrm{pH}-7$.
\end{abstract}

Article History

Received 10.09.2020

Accepted 15.11.2020

Keywords

Bacillus thuringiensis, Protease,

Thermophilic enzyme

\section{Introduction}

Proteases are enzymes with a molecular weight of $18-90 \mathrm{kDa}$ and have a wide range of applications, especially in the food, detergent, textile, leather, pharmaceutical and chemical industries. Approximately $60 \%$ of the industrial protease used in the world is obtained by bacteria (Kobata et al., 1972; Ferrero et al., 1996). Proteases are usually classified according to the optimum pHs which are acidic, neutral and alkaline. A lot of studies were carried on neutral protease. Proteases are not only industrial but also the elucidation of mechanisms involved in thermostability of enzymes (Imanaka et al., 1986; Helmann, 1995). These enzymes are divided into 3 groups as intracellular protease (in cell), periplasmic (with cell wall) and extracellular protease (in medium) (Kohlmann et al., 1991; El-Safey and AbdulRauf, 2004; Nascimento et al., 2004). While intracellular proteases are vital in cellular and

\footnotetext{
${ }^{1}$ Correspondence: onidil@gmail.com
} 
metabolic activities, extracellular proteases are important for obtaining hydrolytic products of proteins in commercial processes (Kalisz, 1988; Kumar and Tagaki, 1999; Gupta et al., 2002). Recently, both extracellular and intracellular protease enzymes have been investigated for industries (Brar et al., 2007).

The protease enzyme derived from Bacillus thuringiensis, which is considered to be an excellent source of protease enzymes, is vital in a wide variety of biological processes such as cell cycle regulation, sporulation, and protoxin activation of biopesticides (Suresh Kumar and Venkateswerlu, 1998; Reddy and Venkateswerlu, 2002). Proteases have appealed the interests of many researchers for a long time and been extensively studied for production from different sources for their cellular role, downstream processing and characterization (Rao et al., 1998; Gupta et al., 2002). However, Bacillus thuringiensis have been studied in literature focused for only their role insecticidal activity. In this study, protease enzyme was purified from Bacillus thuringiensis isolated from soil and characterized. Then, the studies were carried out to figure out the best research conditions of the enzyme in different mediums, at optimum temperatures, at different $\mathrm{pH}$ and in the effect of different metal ions and inhibitors.

\section{Materials and Methods}

\subsection{Isolation of Microorganisms}

The soil samples taken from different fruit gardens in Amasya were inoculated in nutrient broth. Inoculated samples were cultivated at $37^{\circ} \mathrm{C}$ by shaking at $120 \mathrm{rpm}$ for $24 \mathrm{~h}$. The cultures were diluted with physiological saline water and transferred into nutrient agar. Single colony was transferred into skim milk agar for screening protease activity. Protease positive single colony was inoculated into LB medium, which contains peptone from casein $10 \mathrm{~g} / \mathrm{L}$, yeast extract $5 \mathrm{~g} / \mathrm{L}$ and sodium chloride $10 \mathrm{~g} / \mathrm{L}$ and incubated at $25^{\circ} \mathrm{C}, 130 \mathrm{rpm}$ for $24 \mathrm{~h}$. After the incubation, concentration of bacteria was adjusted $\mathrm{OD}_{600}: 0.3$ in $\% 15$ glycerol stock solution and storaged at $-20^{\circ} \mathrm{C}$. $16 \mathrm{~S}$ rRNA sequence analysis were performed with $27 \mathrm{~F}$ and 1492R primer set. 


\subsection{Growth Conditions and Enzyme Sources}

Different growth mediums were used for the cultivation of microorganisms. These mediums are Schaeffer's medium (SG) (containing nutrient broth (difco), $16 \mathrm{~g}$ per liter; $\mathrm{MgSO}_{4} .7 \mathrm{H}_{2} \mathrm{O} 0.5 \mathrm{~g}$ per liter; $\mathrm{KCl} 2.0 \mathrm{~g}$ per liter; $10^{-3} \mathrm{M} \mathrm{Ca}\left(\mathrm{NO}_{3}\right)_{2}, 10^{-4} \mathrm{M} \mathrm{MnCl}_{2}, 10^{-6} \mathrm{M}$ $\mathrm{FeSO}_{4}$ and glucose $0.1 \%$ ), $2 \mathrm{X} \mathrm{SG}$ medium, nutrient broth and tryptose broth (pepton $10 \mathrm{~g}$ per liter; $\mathrm{NaCl} 5 \mathrm{~g}$ per liter). Then, inoculated culture (1\%) was carried into the $1000 \mathrm{ml}$ shaking flask containing $500 \mathrm{ml}$ medium at $25^{\circ} \mathrm{C}$ and $150 \mathrm{rpm}$ for $12,24,36,48,60$ hours on Innova R 40 shaking incubator. The culture was centrifuged at $14.000 \mathrm{rpm}$ for $7 \mathrm{~min}$ at $4^{\circ} \mathrm{C}$. The culture supernatant was used as an extracellular enzyme source. For intracellular enzyme source pellet was washed three times with $50 \mathrm{mM}$ Tris- $\mathrm{HCl}$ buffer $(\mathrm{pH}-8)$ and then pellet was grinded with alümina in porcelain muller. Extract was dissolved in $25 \mathrm{ml}$ of $50 \mathrm{mM}$ Tris- $\mathrm{HCl}$ buffer (pH-8) and was centrifuged at $14.000 \mathrm{rpm}$ for $7 \mathrm{~min}$ at $4^{\circ} \mathrm{C}$. Supernatant was used for intracellular enzyme source.

\subsection{Protease Activity}

Protease activity was measured by hydrolysis of casein $(1 \% \mathrm{w} / \mathrm{v}) \mathrm{pH}-8$ at $37^{\circ} \mathrm{C}$ in shaking water bath during $10 \mathrm{~min}$. Reaction was stopped with TCA 5\%. After centrifugation 14.000 rpm for $7 \mathrm{~min}$. at $4^{\circ} \mathrm{C}$, supernatant was filtered by $0,45 \mu \mathrm{m}$ filter (Johnvesly and Naik, 2001). Absorbance of supernatant was measured at $280 \mathrm{~nm}$.

\subsection{Determination of Protein Content}

The protein content of samples was estimated by the methods (Lowry et al., 1951) using bovine serum albumin as the standart.

\subsection{Purification of Protease}

\subsubsection{Ammonium sulphate precipitation and dialysis}

Proteins were precipitated between 0-20\%, 20-45\% and 45-70\% with ammonium sulphate saturation. Then protein fractions were dissolved in $2.5 \mathrm{ml} 50 \mathrm{mM}$ Tris-HCl buffer (pH-8) and dialyzed against same buffer. 


\subsubsection{DEAE cellulose column chromatography}

The dialysate was put on a jacket column $(1.5 \times 20 \mathrm{~cm})$ of DEAE-cellulose pre-equilibrated with Tris-HCl buffer (pH-8). Column was washed with $80 \mathrm{ml}$ Tris-HCl buffer (pH-8) and then protein fractions were pooled by elution buffer $(80 \mathrm{ml})$ containing $0.05 \mathrm{M}, 0.1 \mathrm{M}, 0.2 \mathrm{M}$ and $0.4 \mathrm{M} \mathrm{NaCl}\left(1 \mathrm{ml}^{-1}\right)$.

\subsubsection{Sephadex G-100 gel filtration}

The active fractions pooled in DEAE cellulose column were selected and put on a jacket column $(1 \times 45 \mathrm{~cm})$ of Sephadex G-100 pre-equilibrated with $50 \mathrm{mM}$ Tris-HCl buffer $(\mathrm{pH}-8)$ $\left(0.5 \mathrm{ml}^{-1}\right)$.

\subsection{Characterization of Protease}

Molecular weight of purified protein was determined with SDS PAGE (Figure 3) (Laemmli, 1970). Zymogram Analysis was executed in PAGE and the staining was done with Commassie brilliant blue-R250 (Figure 4). For thermostability testing, the purified protein was incubated at $25,35,45,55,65$ and $75^{\circ} \mathrm{C}$ for $30 \mathrm{~min}$ in $50 \mathrm{mM}$ Tris-HCl buffer (pH-8) and $1 \%$ casein. For determination of optimum $\mathrm{pH}$, the purified protein was incubated at 6 and $\mathrm{pH}-$ 7 sodium phosphate buffer, 8 and $\mathrm{pH}-9$ Tris- $\mathrm{HCl}$ buffer, 10 and $\mathrm{pH}-11$ in glycine $\mathrm{NaOH}$ buffer and $1 \%$ casein for $30 \mathrm{~min}$. The effects of different ions on protease thermostability were studied by incubating purified protein at $37^{\circ} \mathrm{C}$ in $50 \mathrm{mM}$ Tris- $\mathrm{HCl}$ buffer $(\mathrm{pH}-8)$ containing $5 \mathrm{mM}$ ion concentrations for $30 \mathrm{~min}$. For determining the effect of inhibitors on protease activity, the enzymes solution was pre-incubated with $1 \mathrm{mmol}^{-1}$ of inhibitor such as EGTA, EDTA, PMSF, 1-10 Phenontrolin, SDS, CTAB, Triton, Tween for 30 min at $37^{\circ} \mathrm{C}$ in Tris buffer and then caseinolytic activity was assayed. Afterwards, the residual activities were assayed with $1 \%$ casein as the substrate at $37^{\circ} \mathrm{C}$ for $10 \mathrm{~min}$.

\section{Results}

In our study, the microorganism isolated from soil samples was examined in terms of potential protease production. In addition, optimization of the environment for the maximum protease enzyme production of the bacteria and partial purification of the enzyme were carried 
out. The sequence analysis of the $16 \mathrm{~S}$ rRNA gene region of the strain was confirmed as Bacillus thuringiensis.

In the carried out study, the purification results of the protease from Bacillus thuringiensis are summarized on Table 2. After the final purification step, the protease was purified (Table 1). After grinding with alumina pellet resuspansed with $2.5 \mathrm{ml}$ Tris- $\mathrm{HCl}$ buffer $\mathrm{pH}-8$, ammonium sulphate precipitation, dialysis was performed. Then, ion exchange chromatography was done and one peak was observed (Figure 1).

Table 1. Intracellular protease activity of Bacillus thuringiensis

\begin{tabular}{cccc}
\hline $\begin{array}{c}\text { Incubation Time } \\
(\mathbf{h})\end{array}$ & 1. Result $(\mathbf{U} / \mathbf{m l})$ & 2. Result (U/ml) & 3. Result (U/ml) \\
\hline 12 & 124 & 177 & 118 \\
24 & 387 & 400 & 409 \\
36 & 361 & 343 & 359 \\
48 & 208 & 211 & 221 \\
60 & 168 & 160 & 176 \\
72 & 143 & 157 & 165 \\
\hline
\end{tabular}

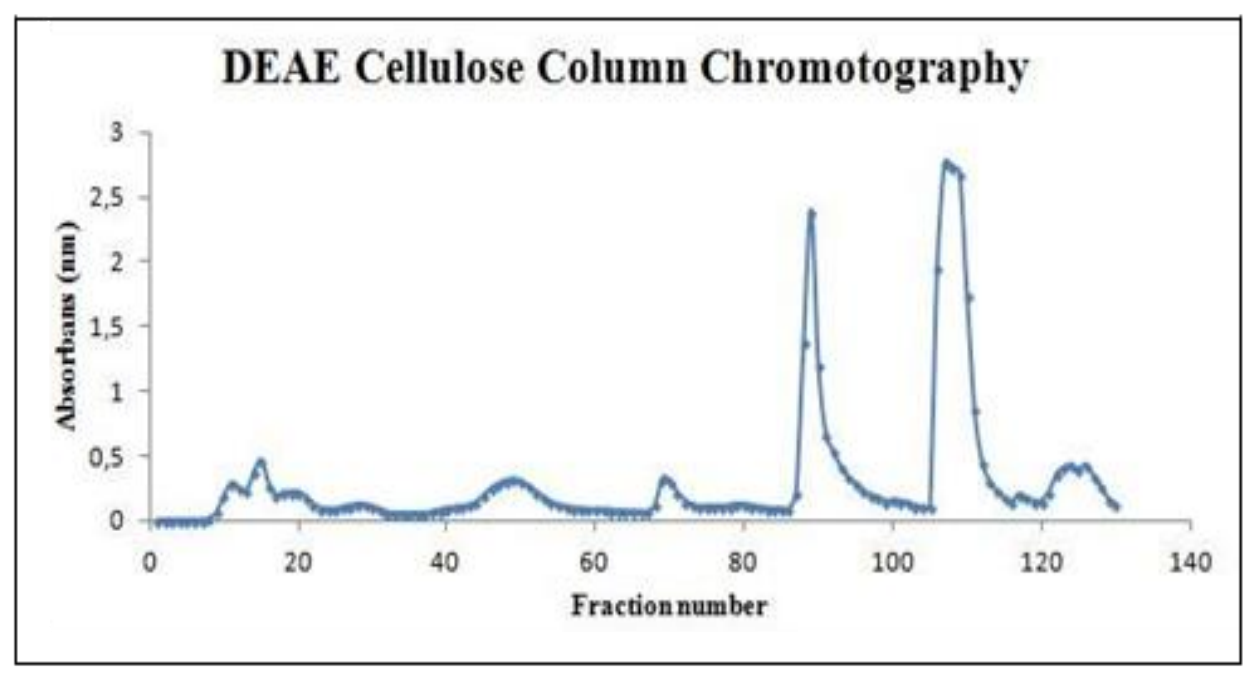

Figure 1. DEAE cellulose column chromatography

108th fraction tube was chosen for gel filtration chromatography (Figure 2) and one type notrale intracellular protease was purified from Bacillus thuringiensis. Specific activity and purification fold values of fractions were given in Table 2. 
Table 2. Protease purification results

\begin{tabular}{cccccc}
\hline & $\begin{array}{c}\text { Activity } \\
\text { Absorbance } \\
(\mathbf{n m})\end{array}$ & Activity & $\begin{array}{c}\text { Protein } \\
\text { Content }\end{array}$ & $\begin{array}{c}\text { Specific } \\
\text { Activity }\end{array}$ & $\begin{array}{c}\text { Purification } \\
\text { Fold }\end{array}$ \\
\hline Crude & 0,711 & 547 & 13,42 & 40,6 & 1 \\
\hline $\begin{array}{c}\text { Ammonium } \\
\text { Sulphate }(0- \\
\text { 20\%) }\end{array}$ & 0,463 & 356 & 5,39 & 66,09 & 1,62 \\
\hline $\begin{array}{c}\text { Ammonium } \\
\text { Sulphate (20- } \\
\text { 45\%) }\end{array}$ & 0,71 & 546 & 17,39 & 31,41 & 0,77 \\
\hline $\begin{array}{c}\text { Ammonium } \\
\text { Sulphate (45- } \\
70 \%)\end{array}$ & 2,14 & 1646 & 27,5 & 59,86 & 1,47 \\
\hline $\begin{array}{c}\text { Dialysis } \\
\text { Ion }\end{array}$ & 1,06 & 815 & 15,75 & 51,74 & 1,27 \\
$\begin{array}{c}\text { Exchange } \\
\left(89^{\text {th }}\right.\end{array}$ & 0,059 & 45,4 & 1,49 & 30,47 & 0,75 \\
fraction) & & & & & \\
\hline $\begin{array}{c}\text { Ion } \\
\text { Exchange } \\
\left(107^{\text {th }}\right. \\
\text { fraction) }\end{array}$ & 0,44 & 338,5 & 0,9 & 376,11 & 9,26 \\
\hline $\begin{array}{c}\text { Gel } \\
\text { Filtration(6 } \\
\text { fraction) }\end{array}$ & 0,095 & 73,08 & 0,09 & 812 & 20 \\
\hline
\end{tabular}

The characterization study was done on the partially purified product obtained after the ammonium sulphate step. The purified enzyme was screened with SDS PAGE (Figure 3) and zymograme analysis was done (Figure 4). Zymography was performed in conjunction with SDS PAGE. Finally, the gel attained with Coomassie Brillant Blue R-250 for zymogram analysis. The development of clear zones on the blue background indicated the presence of the activity. 




Figure 2. Gel filtration column chromatography

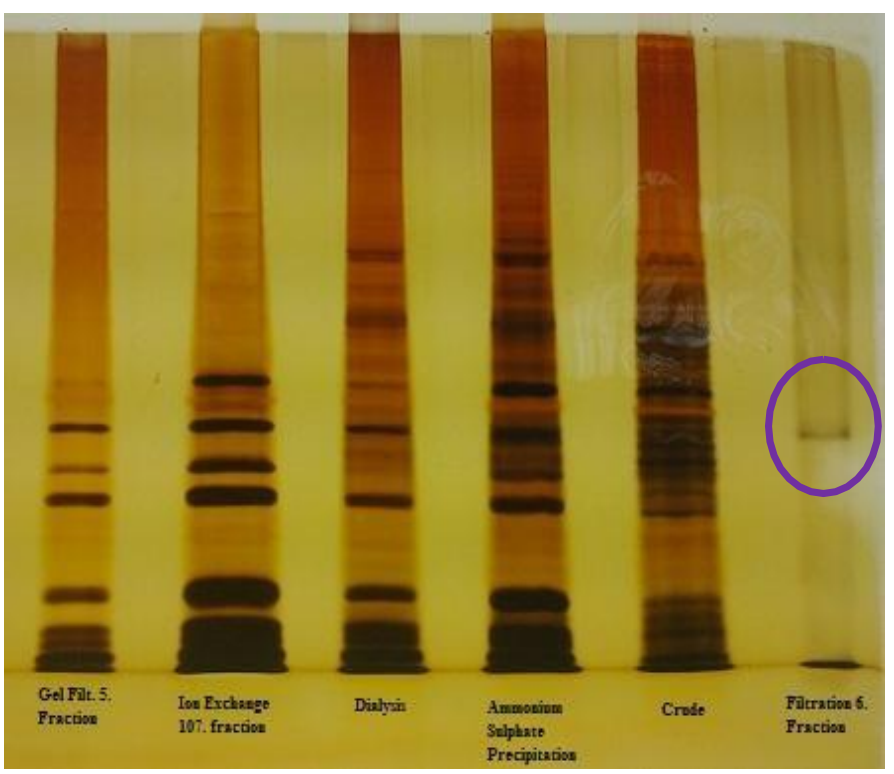

Figure 3. SDS PAGE purification steps

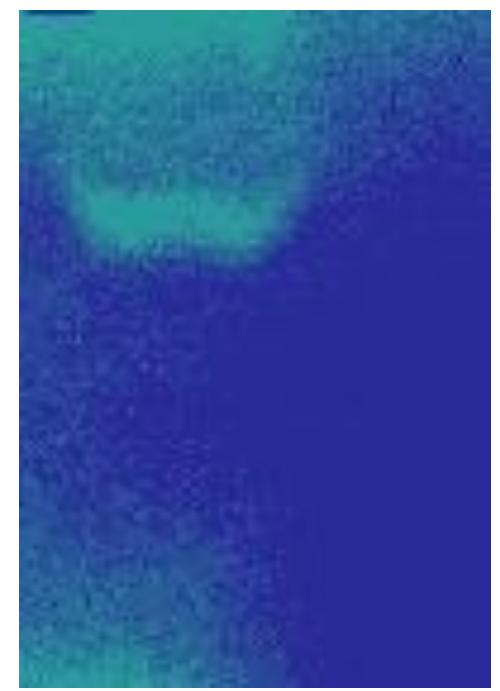

Figure 4. The enzyme zymogram image 
The effect of temperature on the activity of B.thuringiensis protease was examined. It is found out that the maximum activities of the enzyme was at $55^{\circ} \mathrm{C}$ when its activity was controlled and the enzyme was incubated between $25-75^{\circ} \mathrm{C}$ in 30 minutes (Figure 5). Thus, it can be classified as thermophilic protease.



Figure 5. Effect of temperature on protease activity

The effect of $\mathrm{pH}$ on protease activity of the purified enzyme was studied at various $\mathrm{pH}$ values (pH 5-11). Purified enzyme was showed maximum activity at pH 7 (Figure 6).

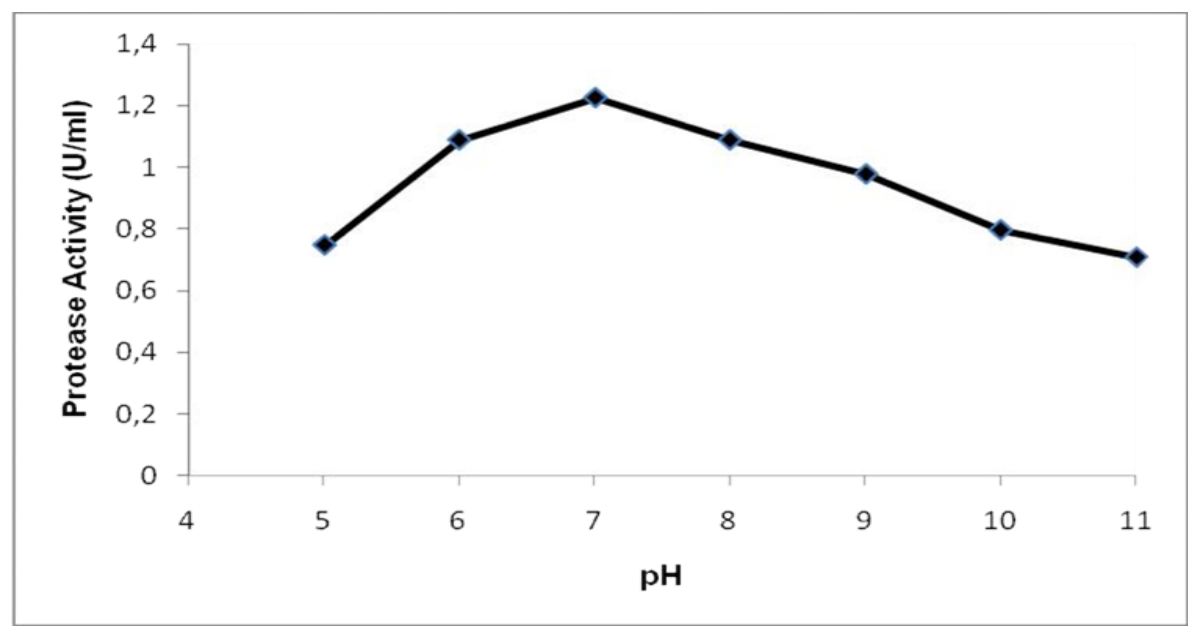

Figure 6. Effect of $\mathrm{pH}$ on protease activity

The effect of various enzyme inhibitors were also investigated (Table 3). It was seen that 1-10 phenanthroline, Tween and SDS were effective inhibitors on the enzyme activity. 
Table 3. Effect of inhibitors on protease activities

\begin{tabular}{cc}
\hline Additives (5mM) & Relativeactivity (\%) \\
\hline Distile water (Control) & 100 \\
Methanol (Control) & 100 \\
CTAB & 105,7411 \\
EDTA & 94,88518 \\
1-10 Phenontrolin & 79,18455 \\
PMSF & 97,2103 \\
Triton X-100 & 104,6973 \\
Tween & 85,38622 \\
SDS & 82,3 \\
\hline
\end{tabular}

The effects of various metal ions were observed on the activity of protease at a concentration of $5 \mathrm{mM}$ (Table 4). Most of the metal ions did not effect the activity or decreased the enzyme activity slightly while $\mathrm{Mg}^{2+}$ inhibited the activity at the ratio of $21 \%$. Five different isolates were obtained from soil samples. Protease activity was observed only in a single isolate onto skim milk agar. In this part of this study, four different growth mediums were used. The results showed that maximum protease activity was observed in SG medium at $37^{\circ} \mathrm{C}$ for 48 and $60 \mathrm{~h}$ (Figure 7). 




Figure 7. Protease activity in different broths

The effect of different metal ions were also investigated (Table 4). It was seen that $\mathrm{Mg}^{2+}$ effective inhibitors on the enzyme activity.

Table 4. The effect of metal ions on Bacillus thuringiensis protease activities

\begin{tabular}{cc}
\hline Metal ions (5mM) & Relative activity (\%) \\
\hline $\mathrm{Cu}^{2+}$ & 95 \\
$\mathrm{Mn}^{2+}$ & 87 \\
$\mathrm{~K}^{+}$ & 86 \\
$\mathrm{Hg}^{2+}$ & 89 \\
$\mathrm{Fe}^{3+}$ & 101 \\
$\mathrm{Na}^{+}$ & 95 \\
$\mathrm{Mg}^{2+}$ & 79 \\
$\mathrm{Ca}^{2+}$ & 97 \\
$\mathrm{Zn}^{2+}$ & 94 \\
$\mathrm{Control}^{2+}$ & 100 \\
\hline
\end{tabular}




\section{Discussion}

Metabolic enzymes that have vital tasks in the cell are molecules in the protein structure that catalyses biochemical reactions and even they enter into our daily and economic life for various purposes. Enzymes used in almost all areas of the industry are generally derived from microorganisms. Enzymes produced from microorganisms have some advantages such as they have high catalytic activities, not to produce undesired side products, more stable and cheaper and they can be produced more comparing to the enzymes produced from plants and animals. These microorganisms are chosen not only for their ability to produce the enzyme but also according not to be non-toxic and pathogenic microorganisms (Eren et al., 2006). Time course for the production of protease by B. thuringiensis was studied at $24 \mathrm{~h}$. Similar results reported (Haddar et al., 2009; Shivanand and Jayaraman, 2009; Bekler et al., 2015; Ahmetoglu et al., 2015 ) the optimum protease production at $24 \mathrm{~h}$. Other study on the optimization of $\mathrm{pH}$ and temperature for production of maximum enzymes as well as thermostability, $\mathrm{pH}$ stability, effect of activators and inhibitors on the proteases (Kaur and Pandy, 2009). Our study also includes optimization factors such as $\mathrm{pH}$, temperature and also effect of inhibitors and activators on the activity of protease enzyme. In Figure 7, the optimum pH was 7.0. Similarly reported the optimum $\mathrm{pH}$ to be 7.0 for protease activity. In the same study done on enzyme activity, it is determined that different fungus displayed optimum activity on $\mathrm{pH}-7$ (Muthulakshmi et al., 2011; Jellouli et al., 2011; Asker et al., 2013; Bekler et al., 2015).

As shown in Figure 8, protease was significantly activated by $\mathrm{Fe}^{3+}$ and $\mathrm{Ca}^{2+}$. It was known that $\mathrm{Ca}^{2+}$ acts as an activator for proteases (Hmidet et al., 2009; Annamalai et al., 2014). An increase in the activity in the presence of $\mathrm{Ca}^{2+}$ can may be due to stabilisation of enzyme (Divakar et al., 2010). Similarly the protease activity was accelerated by $\mathrm{Zn}^{2+}$ and it was inhibited $\mathrm{Mg}^{2+}$ and $\mathrm{Ca}^{2+}$ (Samal et al., 1991).

In Figure 9, it was shown that effect of inhibitors on protease activities. Protease strongly inhibited by EDTA, SDS, Tween and 1-10 Phenontrolin (Ahmetoglu et al., 2015). In previous studies researchers found that $\mathrm{Ca}^{2+}$ activated and EDTA inhibited the protease activity (Wang et al., 2009; Wu et al., 2011). Enzyme was stable in the presence of triton X-100 (Wang et al., 2009). The inhibitory effect of SDS on the protease activity was confirmed the other study (Sellami-Kamoun et al., 2008). Higher enzyme production was found to be at $50^{\circ} \mathrm{C}$. Earlier 
studies report that different species of Bacillus cereus (Kebabci and Cihangir, 2011) and Bacillus licheniformis (Bekler et al., 2015).

As a result, intracellular protease was purified from B.thuringiensis that was isolated from soil. After the purification process, the best research conditions of the enzyme were determined. It was found out that protease displayed the best activity in $\mathrm{pH}-7$ and at $55^{\circ} \mathrm{C}$.

\section{Acknowledgements}

This project was supported by the Scientific Research Found of Amasya University (Project Number: FMB-BAP-13-026).

\section{References}

Ahmetoglu, N., Bekler, F.M., Acer, O., Guven, R.G., Guven, K. 2015. Production, purification and characterisation of thermostable metallo-protease from newly isolated Bacillus sp. KG5, EurAsian Journal of BioSciences, (9): 1-11.

Annamalai, N., Rajeswari, M.V., Balasubramanian, T. 2014. Extraction, purification and application of thermostable and halostable alkaline protease from Bacillus alveayuensis CAS 5 using marine wastes, Food and Bioproducts Processing, 92(4): 335-342.

Asker, M.M., Mahmoud, M.G., El Shebwy, K., el Aziz, M.S.A. 2013. Purification and characterization of two thermostable protease fractions from Bacillus megaterium, Journal of Genetic Engineering and Biotechnology, 11(2): 103-109.

Bekler, F.M., Acer, Ö., Güven, K. 2015. Co-production of thermostable, calcium-independent $\alpha$-amylase and alkali-metallo protease from newly isolated Bacillus licheniformis DV3, Innovative Romanian Food Biotechnology, 16, 21-30.

Brar, S.K., Verma, M., Tyagi, R.D., Surampalli, R.Y., Barnabé, S. et al. 2007. Bacillus thuringiensis proteases: production and role in growth, sporulation and synergism, Process Biochemistry, 42(5): 773-790.

Divakar, K., Priya, J. D. A., Gautam, P. 2010. Purification and characterization of thermostable organic solvent-stable protease from Aeromonas veronii PG01, Journal of Molecular Catalysis B: Enzymatic, 66(3-4): 311-318.

El-Safey, E.M., Abdul-Raouf, U.M. Production, purification and characterization of protease enzyme from Bacillus subtilis. International Conferences for Development and the Environment in the Arab World, 2004, Assiut University, p. 14.

Eren Kiran, Ö., Çomlekcioglu, U., Dostbil, N. 2006. Some microbial enzymes and usage fields in industry, KSU Journal of Science and Engineering, 9: 12-19.

Ferrero, M.A., Castro, G.R., Abate, C.M., Baigori, M.D., Sineriz, F. 1996. Thermostable alkaline proteases of Bacillus licheniformis MIR 29: isolation, production and characterization, Applied Microbiology and Biotechnology, 45(3): 327-332.

Gupta, R., Beg, Q., Lorenz, P. 2002. Bacterial alkaline proteases: molecular approaches and industrial applications, Applied Microbiology and Biotechnology, 59(1): 15-32. 
Haddar, A., Agrebi, R., Bougatef, A., Hmidet, N., Sellami-Kamoun, A. et al. 2009. Two detergent stable alkaline serine-proteases from Bacillus mojavensis A21: purification, characterization and potential application as a laundry detergent additive, Bioresource Technology, 100(13): 3366-3373.

Helmann, J.D. 1995. Compilation and analysis of Bacillus subtilis $\sigma$ A-dependent promoter sequences: evidence for extended contact between RNA polymerse and upstream promoter DNA, Nucleic Acids Research, 23(13): 2351-2360.

Hmidet, N., Ali, N.E.H., Haddar, A., Kanoun, S., Alya, S.K. 2009. Alkaline proteases and thermostable $\alpha$-amylase co-produced by Bacillus licheniformis NH1: Characterization and potential application as detergent additive. Biochemical Engineering Journal, 47(1-3): 7179.

Imanaka, T., Shibazaki, M., Takagi, M. 1986. A new way of enhancing the thermostability of proteases, Nature, 324(6098): 695.

Jellouli, K., Ghorbel-Bellaaj, O., Ayed, H.B., Manni, L., Agrebi, R. 2011. Alkaline-protease from Bacillus licheniformis MP1: purification, characterization and potential application as a detergent additive and for shrimp waste deproteinization, Process Biochemistry, 46(6): 1248-1256.

Johnvesly, B., Naik, G.R. 2001. Studies on production of thermostable alkaline protease from thermophilic and alkaliphilic Bacillus sp. JB-99 in a chemically defined medium, Process Biochemistry, 37(2): 139-144.

Kalisz, H.M. 1988. Microbial proteinases. In Enzyme studies, Springer, Berlin, Heidelberg. pp. 1-65.

Kaur, D., Pandy, A.K. 2009. Partial characterization of bacterial proteases, International Journal of Pharma Recent Research, 1: 12-17.

Kebabci, O., Cihangir, N. 2011. Partial purification of protease by a novel bacterium, Bacillus cereus and enzymatic properties, Journal of Biological and Biochemistry, 39: 39-43.

Kobata, A., Yamashita, K., Tachibana, Y. 1972. Methods in Enzymology. by V. Ginsburg, Academic Press Inc., New York, 28, 262.

Kohlmann, K.L., Nielsen, S.S., Steenson, L.R., Ladisch, M.R. 1991. Production of proteases by psychrotrophic microorganisms, Journal of Dairy Science, 74(10): 3275-3283.

Kumar, C.G., Takagi, H. 1999. Microbial alkaline proteases: from a bioindustrial viewpoint, Biotechnology Advances, 17(7): 561-594.

Laemmli, U.K. 1970. Cleavage of structural proteins during the assembly of the head of bacteriophage T4, Nature, 227(5259): 680.

Lowry, O.H., Rosebrough, N.J., Farr, A.L., Randall, R.J. 1951. Protein measurement with the Folin phenol reagent, Journal of Biological Chemistry, 193: 265-275.

Muthulakshmi, C., Gomathi, D., Kumar, D. G. 2011. Production, purification and characterization of protease by Aspergillus flavus under solid state fermentation, Jordan Journal of Biological Sciences, 147(621): 1-12.

Nascimento, W.C.A.D., Martins, M.L.L. 2004. Production and properties of an extracellular protease from thermophilic Bacillus sp., Brazilian Journal of Microbiology, 35(1-2): 91-96.

Rao, M.B., Tanksale, A.M., Ghatge, M.S., Deshpande, V.V. 1998. Molecular and biotechnological aspects of microbial proteases, Microbiology and Molecular Biology Reviews, 62(3): 597-635.

Reddy, Y.C., Venkateswerlu, G. 2002. Intracellular proteases of Bacillus thuringiensis subsp. kurstaki and a protease-deficient mutant Btk-q, Current Microbiology, 45(6): 0405-0409.

Samal, B.B., Karan, B., Parker, C., Stabinsky, Y. 1991. Isolation and thermal stability studies of two novel serine proteinases from the fungus Tritirachium album Limber, Enzyme and Microbial Technology, 13(1): 66-70. 
Sellami-Kamoun, A., Haddar, A., Ali, N.E.H., Ghorbel-Frikha, B., Kanoun, S. 2008. Stability of thermostable alkaline protease from Bacillus licheniformis RP1 in commercial solid laundry detergent formulations, Microbiological Research, 163(3): 299-306.

Shivanand, P., Jayaraman, G. 2009. Production of extracellular protease from halotolerant bacterium, Bacillus aquimaris strain VITP4 isolated from Kumta coast, Process Biochemistry, 44(10): 1088-1094.

Suresh Kumar, N., Venkateswerlu, G. 1998. Endogenous protease-activated 66-kDa toxin from Bacillus thuringiensis subsp. kurstaki active against Spodoptera littoralis, FEMS Microbiology Letters, 159(1): 113-120.

Wang, S.L., Chao, C.H., Liang, T.W., Chen, C.C. 2009. Purification and characterization of protease and chitinase from Bacillus cereus TKU006 and conversion of marine wastes by these enzymes, Marine Biotechnology, 11(3): 334-344.

Wu, Y.Y., Wang, H.X., Ng, T.B. 2011. A novel metalloprotease from the wild basidiomycete mushroom Lepista nuda, Journal of Microbiology and Biotechnology, 21(3): 256-262. 